\title{
Bio-Efficacy of Fungicides against Magnaporthe oryzae Causing Blast of Rice
}

\author{
D. Vidyashankar*, B. C. Kamanna and P. Nagaraju \\ Department of Plant Pathology, College of Agriculture, Dharwad \\ University of Agricultural Sciences, Dharwad - 580 005, India \\ *Corresponding author
}

\section{A B S T R A C T}

\section{Keywords}

Rice, leaf blast, mycelial growth inhibition,

fungicides,

Magnaporthe

oryzae

Article Info

Accepted:

25 February 2020

Available Online:

10 March 2020
The present in-vitro study was conducted at the Department of Plant Pathology, University of Agricultural Sciences, Dharwad, Karnataka, India during July 2018, to evaluate different fungicides against rice blast incited by Magnaporthe oryzae Couch and Kohn. Among the four contact fungicides tested, propineb $70 \%$ WP recorded cent per cent inhibition of mycelial growth in all the concentrations (i.e., $1000 \mathrm{ppm}, 1500 \mathrm{ppm}$ and $2000 \mathrm{ppm}$ ), mancozeb $75 \%$ WP recorded next highest inhibition of mycelial growth. Among the eight systemic fungicides, complete inhibition of mycelial growth of the fungus was recorded in all the concentration (i.e., $500 \mathrm{ppm}, 750 \mathrm{ppm}$ and $1000 \mathrm{ppm}$ ) in six fungicides viz., propiconazole $25 \%$ EC, carbendazim $50 \% \mathrm{WP}$, thiophanate methyl $70 \% \mathrm{WP}$, tebuconazole $25 \% \mathrm{EC}$, isoprothiolane $5 \% \mathrm{EC}$ and tricyclazole $75 \%$. Minimum inhibition was observed in azoxystrobin $25 \% \mathrm{SC}$, with 55.83, 63.62 and 70.52 per cent inhibition at 500, 750 and $1000 \mathrm{ppm}$ concentration respectively with a mean of 63.66 per cent. In general, the inhibition of radial growth of fungus increased with increase in concentration of each fungicide.

\section{Introduction}

Rice (Oryza sativa L.) is a self-pollinated crop belongs to the botanical family Poaceae (Gramineae), tribe Oryzeae. It is one of the maximum critical plants of the area both in phrases of place and production, approximately 90 per cent of global rice is grown and fed on in Asia and 60 in line with cent of world population additionally depends on rice for their half of the calorie consumption from this crop. Rice is consumed in diverse paperwork like roti, boiled rice, puffed rice, idli, canned rice and fermented products, dosa and so on.

In rice production, China leading the list and India stands next to it but India stands first in global area of rice cultivation. Rice contributes around 43 per cent of total food grain production and 55 per cent of cereals production in the country; in world rice is 
grown in an area of 157.46 million hectares with the production of 503.80 million tonnes and in India rice is cultivated in 43.41 million hectares with a production of 112.91 million tonnes during 2017-18 (Anon., 2018).

Rice suffers from many diseases caused by fungi, bacteria, viruses, phytoplasma, nematodes and other non-parasitic disorders. Among the fungal diseases, blast is considered as a major threat to rice production because of its wide spread distribution and its destructiveness under favourable conditions (Webster and Gunnell, 1992).

There are several methods practiced to combat the problem of blast disease but disease management through fungicide plays a very crucial role as many high yielding and popular varieties have become susceptible to the disease.

Rice blast caused by Magnaporthe oryzae Couch and Kohn (Anamorph: Pyricularia oryzae Cavara) belongs to ascomycetes known to infect quite 50 hosts. Rice blast was $1^{\text {st }}$ came into notice in China (1637) later from Japan (1704). In India, the disease gained importance once a devastating epidemic occurred in Thanjavur (Tanjore) delta of Tamilnadu throughout 1919 (Nagarajan, 1988).

The pathogen may infect all the above ground parts of a rice plant at different growth stages viz., leaf, collar, node, internodes, base or neck and other parts of the panicle and sometimes the leaf sheath. A typical blast lesion on a rice leaf is gray at the centre, has a dark border and it is spindle-shaped.

\section{Materials and Methods}

The efficacy of different fungicides was assayed. The fungicides were tested against the $M$. oryzae by following 'Poisoned food technique'. The required concentrations of chemicals were weighed and incorporated into sterilized, cooled potato dextrose agar. Twenty $\mathrm{ml}$ of cooled molten medium was poured into $90 \mathrm{~mm}$ sterilized Petri dishes and all plates were inoculated with actively growing five $\mathrm{mm}$ mycelial disc of pathogen separately.

Three replications were maintained for each treatment. These plates were incubated at 27 $\pm 1^{0} \mathrm{C}$ for 12-14 days, and colony diameter was recorded. The per cent inhibition of growth was calculated by using the formula given by Vincent (1947).

$$
I=\frac{(C-T)}{C} \times 100
$$

Where,

$\mathrm{I}=$ Per cent inhibition of mycelial growth

$\mathrm{C}=$ Growth of mycelium in control.

$\mathrm{T}=$ Growth of mycelium in treatment.

\section{List of fungicides used for in vitro evaluation}

\section{Contact fungicides}

The following contact fungicides were evaluated at 1000, 1500 and 2000 ppm concentrations.

\begin{tabular}{|c|l|l|}
\hline Sl. No. & \multicolumn{1}{|c|}{ Common name } & \multicolumn{1}{|c|}{$\begin{array}{c}\text { Trade } \\
\text { name }\end{array}$} \\
\hline 1. & $\begin{array}{l}\text { Copper hydroxide 35\% } \\
\text { WG }\end{array}$ & $\begin{array}{l}\text { Kocide } \\
2000\end{array}$ \\
\hline 2. & Propineb 70 \% WP & Antracol \\
\hline 3. & Mancozeb 75 \% WP & $\begin{array}{l}\text { Indofil } \\
\text { M-45 }\end{array}$ \\
\hline 4. & Chlorothalonil 75 \% WP & Kavach \\
\hline
\end{tabular}

\section{Systemic fungicides}

The following systemic fungicides were 
evaluated at 500, 750 and $1000 \mathrm{ppm}$ concentrations.

\begin{tabular}{|c|l|l|}
\hline $\begin{array}{c}\text { Sl. } \\
\text { No. }\end{array}$ & \multicolumn{1}{|c|}{ Common name } & $\begin{array}{l}\text { Trade } \\
\text { name }\end{array}$ \\
\hline 1. & Azoxystrobin $25 \% \mathrm{SC}$ & Amistar \\
\hline 2. & $\begin{array}{l}\text { Thiophanate methyl } 70 \% \\
\text { WP }\end{array}$ & Roko \\
\hline 3. & Propiconazole 25 \% EC & Tilt \\
\hline 4. & Difenconazole 25\% EC & Score \\
\hline 5. & Tricyclazole 75 \% WP & Beam \\
\hline 6. & Carbendazim 50 \% WP & Bavistin \\
\hline 7. & Tebuconazole 25 \% EC & Folicur \\
\hline 8. & Isoprothiolane 5 \% EC & Fujione \\
\hline
\end{tabular}

\section{Results and Discussion}

Efficacy of four contact and eight systemic fungicides was tested at three different concentrations by poison food technique as per the procedure explained in Material and Methods. The results obtained on testing efficacy of fungicides against the $M$. oryzae are depicted in Table 1, 2 and Plate 1, 2.

\section{Contact fungicides}

Among the three different concentrations tested, the maximum mean inhibition of mycelial growth (100\%) among the fungicides was recorded in propineb $70 \%$ WP, followed by mancozeb $75 \%$ WP $(90.85$ $\%)$ and the least mean inhibition of mycelial growth $(37.25 \%)$ was recorded in case of copper hydroxide $35 \%$ WG whereas, maximum mean inhibition of mycelial growth $(80.78 \%)$. Among the concentrations was recorded in $2000 \mathrm{ppm}$, followed by $1500 \mathrm{ppm}$ $(74.12 \%)$ and the least mean inhibition of mycelial growth $(66.67 \%)$ was recorded in case of $1000 \mathrm{ppm}$. In all the three tested concentrations viz., $1000 \mathrm{ppm}, 1500 \mathrm{ppm}$ and 2000 ppm, propineb $70 \%$ WP recorded cent per cent inhibition of mycelial growth, mancozeb $75 \%$ WP was the next best non systemic fungicide in all the concentrations (84.31 \%, $89.80 \%$ and $98.43 \%$, respectively). The least effectiveness in all the three concentration was seen in copper hydroxide $35 \%$ WG $(28.63 \%, 38.04 \%$ and $45.10 \%$, respectively). So, propineb $70 \%$ WP found to be the best non systemic fungicide at all the concentrations and mancozeb $75 \%$ WP found to be the next best non systemic fungicide. Gohel et al., (2008) and Hajano et al., (2012) also recorded similar types of results.

\section{Systemic fungicides}

Among the fungicides, the highest inhibition of mycelial growth $(100 \%)$ was recorded in six fungicides viz., propiconazole $25 \% \mathrm{EC}$, carbendazim $50 \% \mathrm{WP}$, Thiophanate methyl $70 \%$ WP, tebuconazole $25 \%$ EC, isoprothiolane $5 \% \mathrm{EC}$ and tricyclazole $75 \%$ WP at all the three concentrations whereas, the least was recorded in case of azoxystrobin $25 \%$ SC $(70.20 \%)$. Maximum mean inhibition of mycelial growth (90.85 \%) among the fungicides was recorded in six fungicides viz., propiconazole $25 \% \mathrm{EC}$, carbendazim $50 \% \mathrm{WP}$, Thiophanate methyl $70 \%$ WP, tebuconazole $25 \%$ EC, isoprothiolane $5 \% \mathrm{EC}$ and tricyclazole $75 \%$ WP, followed by difenconazole $25 \%$ and the least mean inhibition of mycelial growth $(74.38 \%)$ was recorded in case of azoxystrobin $25 \%$ SC whereas, the maximum mean inhibition of mycelial growth $(97.25 \%)$ among the concentrations was recorded at $1000 \mathrm{ppm}$, followed by $750 \mathrm{ppm}(95.59 \%)$ and the least mean inhibition of mycelial growth $(94.12 \%)$ was recorded at $500 \mathrm{ppm}$. 
Table.1 In Vitro evaluation of contact fungicides against M. Oryzae

\begin{tabular}{|c|c|c|c|c|c|}
\hline \multirow[t]{2}{*}{ Treatment } & \multirow[t]{2}{*}{ Fungicides } & \multicolumn{3}{|c|}{ Per cent mycelial growth inhibition } & \multirow[t]{2}{*}{ Mean } \\
\hline & & 1000 ppm & 1500 ppm & 2000 ppm & \\
\hline $\mathbf{T}_{1}$ & Propineb $70 \% \mathrm{WP}$ & $\begin{array}{c}100.00 \\
(90.00)^{*}\end{array}$ & $\begin{array}{l}100.00 \\
(90.00)\end{array}$ & $\begin{array}{l}100.00 \\
(90.00)\end{array}$ & $\begin{array}{l}100.00 \\
(90.00)\end{array}$ \\
\hline $\mathbf{T}_{2}$ & Mancozeb 75\% WP & $\begin{array}{c}84.31 \\
(66.67)\end{array}$ & $\begin{array}{c}89.80 \\
(71.37)\end{array}$ & $\begin{array}{c}98.43 \\
(82.80)\end{array}$ & $\begin{array}{r}90.85 \\
(72.39)\end{array}$ \\
\hline $\mathbf{T}_{3}$ & Chlorothalonil 75\% WP & $\begin{array}{c}53.73 \\
(47.14)\end{array}$ & $\begin{array}{c}68.63 \\
(55.94)\end{array}$ & $\begin{array}{c}79.61 \\
(63.16)\end{array}$ & $\begin{array}{c}67.32 \\
(\mathbf{5 5 . 1 3})\end{array}$ \\
\hline $\mathbf{T}_{4}$ & Copper hydroxide $35 \%$ WG & $\begin{array}{c}28.63 \\
(32.35)\end{array}$ & $\begin{array}{c}38.04 \\
(38.08)\end{array}$ & $\begin{array}{c}45.10 \\
(42.19)\end{array}$ & $\begin{array}{r}37.25 \\
(37.61)\end{array}$ \\
\hline \multirow{2}{*}{\multicolumn{2}{|c|}{ Mean }} & $\begin{array}{c}66.67 \\
(54.74)\end{array}$ & $\begin{array}{c}74.12 \\
(59.42)\end{array}$ & $\begin{array}{c}80.78 \\
(64.00)\end{array}$ & \\
\hline & & S.Em. \pm & C.D. @ $1 \%$ & & \\
\hline & Fungicide (F) & 0.60 & 1.75 & & \\
\hline \multicolumn{2}{|r|}{ Concentration (C) } & 0.52 & 1.51 & & \\
\hline \multicolumn{2}{|c|}{ Fungicide $\times$ Concentration $(\mathbf{F} \times \mathbf{C})$} & 1.04 & 3.03 & & \\
\hline
\end{tabular}

*Arc sine transformed values

Table.2 In vitro evaluation of systemic fungicides against M. oryzae

\begin{tabular}{|c|c|c|c|c|c|}
\hline \multirow[t]{2}{*}{ Treatment } & \multirow[t]{2}{*}{ Fungicides } & \multicolumn{3}{|c|}{ Per cent mycelial growth inhibition } & \multirow[t]{2}{*}{ Mean } \\
\hline & & 500 ppm & 750 ppm & $1000 \mathrm{ppm}$ & \\
\hline $\mathbf{T}_{1}$ & Azoxystrobin $25 \%$ SC & $\begin{array}{c}70.20 \\
(56.91)^{*}\end{array}$ & $\begin{array}{c}74.90 \\
(59.93)\end{array}$ & $\begin{array}{c}78.04 \\
(62.06)\end{array}$ & $\begin{array}{c}74.38 \\
(59.59)\end{array}$ \\
\hline $\mathbf{T}_{2}$ & Difenoconazole $25 \%$ EC & $\begin{array}{c}82.75 \\
(65.46)\end{array}$ & $\begin{array}{c}89.80 \\
(71.37)\end{array}$ & $\begin{array}{l}100.00 \\
(90.00)\end{array}$ & $\begin{array}{r}90.85 \\
(72.39)\end{array}$ \\
\hline $\mathbf{T}_{3}$ & Propiconazole $25 \%$ EC & $\begin{array}{l}100.00 \\
(90.00)\end{array}$ & $\begin{array}{l}100.00 \\
(90.00)\end{array}$ & $\begin{array}{l}100.00 \\
(90.00)\end{array}$ & $\begin{array}{l}100.00 \\
(90.00)\end{array}$ \\
\hline $\mathbf{T}_{4}$ & Carbendazim 50\% WP & $\begin{array}{l}100.00 \\
(90.00)\end{array}$ & $\begin{array}{l}100.00 \\
(90.00)\end{array}$ & $\begin{array}{l}100.00 \\
(90.00)\end{array}$ & $\begin{array}{l}100.00 \\
(90.00)\end{array}$ \\
\hline $\mathbf{T}_{5}$ & Thiophanate methyl 70\% WP & $\begin{array}{r}100.00 \\
(90.00)\end{array}$ & $\begin{array}{l}100.00 \\
(90.00)\end{array}$ & $\begin{array}{l}100.00 \\
(90.00)\end{array}$ & $\begin{array}{l}100.00 \\
(90.00)\end{array}$ \\
\hline $\mathbf{T}_{6}$ & Tebuconazole $25 \%$ EC & $\begin{array}{l}100.00 \\
(90.00)\end{array}$ & $\begin{array}{l}100.00 \\
(90.00)\end{array}$ & $\begin{array}{l}100.00 \\
(90.00)\end{array}$ & $\begin{array}{l}100.00 \\
(90.00)\end{array}$ \\
\hline $\mathbf{T}_{7}$ & Isoprothiolane 5\% EC & $\begin{array}{l}100.00 \\
(90.00)\end{array}$ & $\begin{array}{l}100.00 \\
(90.00)\end{array}$ & $\begin{array}{l}100.00 \\
(90.00)\end{array}$ & $\begin{array}{l}100.00 \\
(90.00)\end{array}$ \\
\hline $\mathbf{T}_{8}$ & Tricyclazole $75 \% \mathrm{WP}$ & $\begin{array}{l}100.00 \\
(90.00)\end{array}$ & $\begin{array}{l}100.00 \\
(90.00)\end{array}$ & $\begin{array}{l}100.00 \\
(90.00)\end{array}$ & $\begin{array}{l}100.00 \\
(90.00)\end{array}$ \\
\hline \multirow{2}{*}{\multicolumn{2}{|c|}{ Mean }} & $\begin{array}{c}94.12 \\
(75.97)\end{array}$ & $\begin{array}{c}95.59 \\
(77.88)\end{array}$ & $\begin{array}{c}97.25 \\
(80.45)\end{array}$ & \\
\hline & & S.Em. \pm & C.D.@1\% & & \\
\hline & Fungicide (F) & 0.89 & 1.80 & & \\
\hline & Concentration (C) & 0.55 & 1.10 & & \\
\hline \multicolumn{2}{|c|}{ Fungicide $\times$ Concentration $(\mathrm{F} \times \mathbf{C})$} & 1.55 & 3.12 & & \\
\hline
\end{tabular}

*Arc sine transformed values 


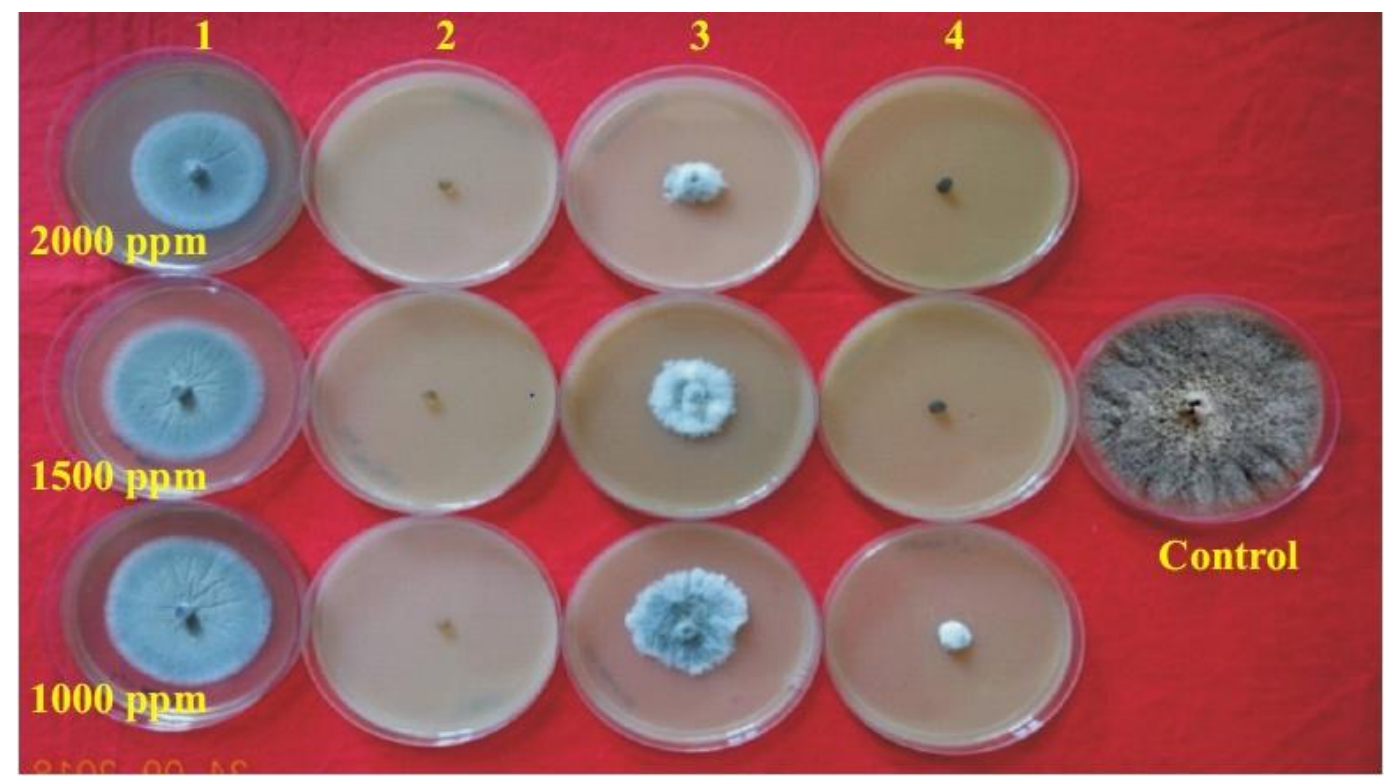

Plate.1 In vitro efficacy of contact fungicides against $M$. oryzae

Where, Copper hydroxide 35\% WG; Propineb 70\% WP; Chlorothalonil 75\% WP;

Mancozeb 75\% WP

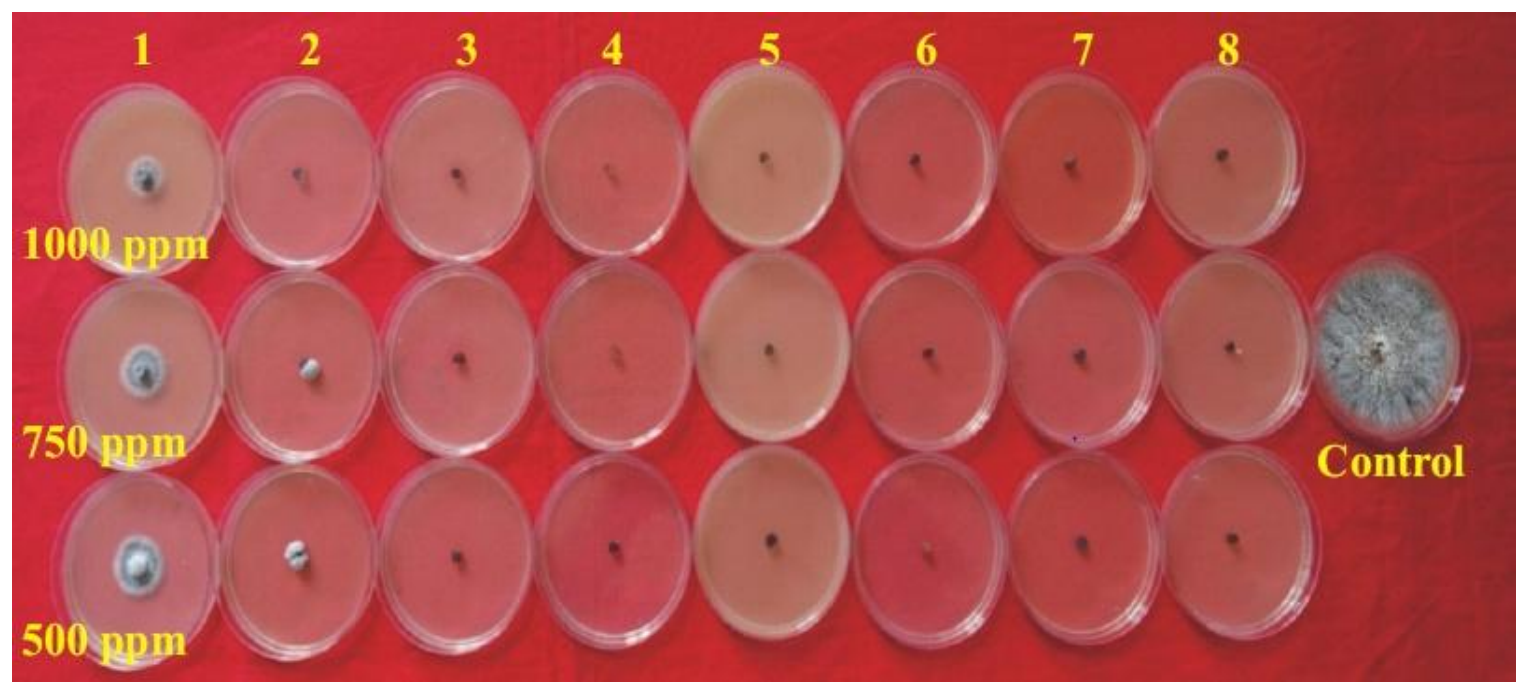

Plate.2 In vitro efficacy of systemic fungicides against $M$. oryzae

Where, Azoxystrobin $25 \%$ SC ; Difenoconazole $25 \%$ EC; Tebuconazole 25\% EC; Isoprothiolane 5\% EC ; Carbendazim 50\% WP; Propiconazole 25\% EC; Tricyclazole 75\% WP; Thiophanate methyl 70\% WP

In all the three tested concentrations viz., 500 ppm, $750 \mathrm{ppm}$ and $1000 \mathrm{ppm}$, six fungicides have recorded cent per cent inhibition of mycelial growth, difenconazole $25 \%$ EC found to be the next best systemic fungicide in all the concentrations $(82.75 \%, 89.80 \%$ and $100.00 \%$, respectively). Least effectiveness in all the three concentration was seen in azoxystrobin $25 \%$ SC (70.20\%,
$74.90 \%$ and $78.04 \%$, respectively). Majority of the fungicides which had shown cent per cent inhibition belong to triazole group. Which are strong ergosterol biosynthesis inhibitors in the fungal membrane. Ergosterol is essential for cell wall structure and inhibition of sterol biosynthesis will be deleterious to fungal cell (Dupont et al., 2012). 
In conclusion in vitro effectiveness of twelve fungicides comprising of four contact and eight systemic were tested at three different concentrations against $M$. oryzae. The obtained results revealed that, in all the concentrations tested seven fungicides viz., propineb $70 \% \mathrm{WP}$, propiconazole $25 \% \mathrm{EC}$, carbendazim $50 \% \mathrm{WP}$, Thiophanate methyl $70 \%$ WP, tebuconazole $25 \%$ EC, isoprothiolane $5 \% \mathrm{EC}$, tricyclazole $75 \% \mathrm{WP}$ have shown cent per cent mycelial growth inhibition over control.

\section{Acknowledgement}

The author wishes to thank Professor B.C. Kamanna, University of Agricultural Sciences, Dharwad, for his sustained interest in this work and the preparation of this paper.

\section{References}

Anonymous. 2018. The area under cultivated rice in India. Ministry of Farmers Welfare, GOI, New Delhi, www. India stat.com, pp. 51.

Dupont, S., Lemetais, G., Ferreira, T., Coyot, P. and Gervais, P. 2012. Ergosterol biosynthesis: A fungal pathway for life on land. Evolution, 66 (9): 2961-2968.

Gohel, N.M., Chauhan, H.L. and Mehta, A.N. 2008. Bio-efficacy of fungicides against $P$. oryzae the incitant of rice blast. $J$. Plant Dis. Sci., 3 (2):189-192.

Hajano, J.U., Lodhi, A.M., Pathan, M.A., Khanzada, M.A. and Shah, G.S. 2012. In Vitro evaluation of fungicides, plant extracts and bio-control agents against rice blast pathogen Magnaporthe oryzae Couch. Pakistan J. Bot., 44 (5): 17751778.

Nagarajan, S. 1988. Epidemiology and loss of rice, wheat and pearl millet crops due to diseases. In: International Symposium on Crop Losses and Diseases Outbreaks in Tropics and Control measures. Tropical Agriculture Research Centre, Japan. pp. 209.

Vincent, J.M. 1947. Methods for the study of their fungi static properties. J. Soc. Chem. Ind. London., 16: 746-755.

Webster, R.K. and Gunnell, P.S. 1992. Compendium of Rice Diseases. The American Phytopathological Society, St. Paul, MN.86.

\section{How to cite this article:}

Vidyashankar. D., B. C. Kamanna and Nagaraju. P. 2020. Bio-Efficacy of Fungicides against Magnaporthe oryzae Causing Blast of Rice. Int.J.Curr.Microbiol.App.Sci. 9(03): 3042-3047. doi: https://doi.org/10.20546/ijcmas.2020.903.348 